Epidemiologische aspecten van zelfmoordgedrag in Vlaanderen - 1990-2001 Peer-reviewed author version

DE CLERCK, Sara; MERTENS, Tinne; MANSHOVEN, Joke; Vanhove, R. \& VINCK, Jan (2006) Epidemiologische aspecten van zelfmoordgedrag in Vlaanderen 1990-2001. In: Tijdschrift voor Geneeskunde, 62(17). p. 1225-1238.

Handle: http://hdl.handle.net/1942/1348 


\section{EPIDEMIOLOGISCHE ASPECTEN VAN ZELFMOORDGEDRAG IN VLAANDEREN -}

1990-2001 ${ }^{1}$

S. De Clerck², T. Mertens ${ }^{2}$, J. Manshoven², R. Vanhove ${ }^{3}$, J. Vinck ${ }^{2,4}$

1. Onderzoek uitgevoerd in het kader van het pilootproject "Recidivepreventie suïcidepogers in samenwerking met huisartsen”, gerealiseerd in opdracht met de financiële steun van het ministerie van de Vlaamse Gemeenschap.

2. SEIN, Onderzoeksgroep Gezondheidspsychologie, Universiteit Hasselt.

3. Dienst Ambulante Geestelijke Gezondheidszorg (DAGG), Project Zelfmoordpreventie (CGG).

4. Correspondentieadres: prof. dr. J. Vinck, Onderzoeksgroep Gezondheidspsychologie, Universiteit Hasselt, campus Diepenbeek, Agoralaan gebouw D, 3590 Diepenbeek; e-mail: jan.vinck@uhasselt.be 


\section{Samenvatting}

De evolutie van suïcidaal gedrag van 1990 tot 2001 in Vlaanderen wordt besproken. De zelfmoordsterftecijfers in 2001 vertonen een stijging ten opzichte van deze van 1990. Deze cijfers liggen hoger dan deze in de buurlanden, waar in dezelfde periode het aantal zelfmoorden daalt. De verklaring van dit verschil blijft onduidelijk. De toename in het aantal zelfmoorden is meer uitgesproken bij de mannen dan bij de vrouwen. Enkel in de oudste leeftijdscategorieën daalt dit aantal.

Zelfmoord is de tweede belangrijkste doodsoorzaak bij de jongeren (15- tot 24-jarigen) en de voornaamste doodsoorzaak bij mannen in de leeftijdscategorie 25 tot 44 jaar. In de oudere leeftijdscategorieën neemt het relatieve aantal overlijdens door zelfmoord bij beide geslachten af.

Het aantal zelfmoordpogingen in Vlaanderen kan geschat worden op 79 tot 146 pogingen per 100000 Vlamingen. Afhankelijk van de registratiemethode kwam 51,8 of 29,3\% daarvan eerst onder de aandacht van de huisarts. Het merendeel van de pogingen werd gevolgd door een hospitalisatie.

Indien er geen reden is om aan te nemen dat de stijgende tendens intussen is omgebogen, is op korte termijn een stoppen van de stijgende tendens een realistischer objectief op bevolkingsniveau dan een daling met $8 \%$, zoals werd voorgesteld in 2002 op de Vlaamse gezondheidsconferentie "Preventie van depressie en zelfmoord". 


\section{Abstract}

\section{Epidemiological aspects of suicidal behaviour in Flanders - 1990-2001}

The evolution between 1990 and 2001 in suicidal behaviour in Flanders was analysed. The suicide rates for 2001 constitute an increase in comparison to 1990. These figures are higher than in neighbouring countries, where suicide rates decreased during the same period. The interpretation of this difference remains unclear. The increase in suicide rate is more pronounced in men than in women. Only in the eldest groups we see a decrease in suicide rates.

Suicide is the second most important cause of death in the youngest age group (15-24 years of age) and the most important cause of death in 25-44 year old men. In older age groups the importance of suicide in comparison with other causes of death decreases. In males as well as in females, there was little evolution in the methods used to commit suicide.

Depending on the registration method, we estimate the number of suicide attempts between 79 to 146 per 100 000 inhabitants. In between 29.3 and $51.8 \%$ of the cases these attempts are brought to the attention of the general practitioner in the first place, and the majority are subsequently hospitalised. 


\section{Inleiding}

Zelfmoord is een belangrijk persoonlijk, sociaal en maatschappelijk probleem. Het wijst bij de betrokken persoon op een diepgaande crisis met hopeloosheid en depressiviteit als dominante gevoelens. In de omgeving van de potentiële zelfdoder leidt de vrees voor zelfmoord eveneens tot hevige angst, gevoelens van machteloosheid, vaak ook schuldgevoelens wegens de onmacht om de situatie voor de betrokkene voldoende leefbaar te maken. Maatschappelijke evoluties kunnen het risico op zelfmoord mee beïnvloeden (1), en het herkennen en behandelen van risicofactoren voor zelfmoord is een belangrijke maatschappelijke opdracht. Op bevolkingsniveau gaat zelfmoord gepaard met verlies van een aanzienlijk aantal potentiële levensjaren. Zelfmoordgedrag is nooit het gevolg van één enkele oorzaak. Uiteraard speelt het gevoel van onoplosbaarheid van persoonlijke en/of sociale problemen vaak een belangrijke rol. Meer algemeen moeten uitingen van zelfmoord beschouwd worden als “een signaal van een verstoring van een evenwicht waarbij psychologische, biologische en omgevingsgebonden factoren een rol spelen” (2).

Hawton en van Heeringen komen in hun handboek tot het besluit dat er nog heel wat onderzoek nodig is naar de oorzaken, de preventie en de behandeling van dit ernstige probleem (3). Meer specifiek wordt hier, onder meer, gedoeld op onderzoek naar de relaties en interacties tussen biologische, psychologische en sociologische factoren, de genetische basis van zelfmoordgedrag, de identificatie van hoogrisicogroepen en de effectiviteit van psychotherapeutische behandelingsstrategieën (3). Het epidemiologisch onderzoek is hierbij één van de noodzakelijke onderzoekslijnen. Op basis van epidemiologisch onderzoek is het mogelijk de evolutie van het probleem te volgen en groepen, gekenmerkt door een verhoogd risico op suïcidaal gedrag, te omschrijven (2). Voor de ontwikkeling van behandel- en preventiestrategieën is deze kennis onontbeerlijk. Epidemiologisch onderzoek naar zelfmoordgedrag in Vlaanderen is echter schaars. Dit artikel heeft ten doel een bijdrage te leveren om deze leemte op te vullen. We hernemen hierbij voor een deel de analyses die door Moens et al. in 1999 gemaakt werden over ditzelfde onderwerp (4). In hun artikel beschreven deze laatsten de evolutie van de epidemiologische aspecten van zelfmoord(pogingen) aan de hand van de - op dat ogenblik - meest recente cijfers. Deze cijfers dateren van de periode tot 1995, tien jaar geleden. In dit artikel wordt de evolutie tot 2001 beschreven, gebruikmakend van de nu beschikbare gegevens.

Om te beginnen worden de gegevens over de recente evolutie van de omvang van het probleem van zelfmoord in Vlaanderen besproken. Vervolgens wordt de betekenis van deze gegevens verduidelijkt door ze te situeren in een internationale context, en ze te vergelijken met overlijden door andere belangrijke ziekten.

Aansluitend wordt getracht de economische impact van zelfmoord weer te geven - in vergelijking met enkele andere doodsoorzaken - aan de hand van het aantal potentiële levensjaren. Hierna wordt de evolutie van de bij zelfmoord gebruikte middelen bekeken. Na de bespreking van de epidemiologische gegevens in verband met zelfmoord wordt tenslotte ingegaan op de bestaande gegevens over zelfmoordpogingen.

Gezien de complexiteit van het probleem, kunnen een aantal weliswaar belangrijke aspecten hier niet behandeld worden, zoals de oorzaken van zelfmoordgedrag of de verschillende risicofactoren met inbegrip van psychiatrische stoornissen. Evenmin kan hier worden stilgestaan bij de processen die uiteindelijk kunnen leiden tot zelfmoordgedrag. Voor een groot deel van deze aspecten wordt verwezen naar Hawton en van Heeringen (3). 


\section{Methode}

Om de genoemde aspecten te onderzoeken, wordt beroep gedaan op de meest recente registratiegegevens. Er wordt gebruikt gemaakt van de inspanningen die de Administratie Gezondheidszorg van het ministerie van de Vlaamse Gemeenschap leverde om de Gezondheidsindicatoren zo recent mogelijk te houden (5). Voor de internationale cijfers wordt te rade gegaan bij de “European Health for all database” (6). Daarnaast wordt gebruik gemaakt van de registratiegegevens van de huisartsenpeilpraktijken (Wetenschappelijk Instituut Volksgezondheid, Peilpraktijken 2001) en van de Eenheid voor Zelfmoordonderzoek van de Universiteit Gent (Eenheid voor Zelfmoordonderzoek, Universiteit Gent, onder subsidie van het ministerie van de Vlaamse Gemeenschap).

De situatie in Vlaanderen wordt beschreven, omdat de cijfers met betrekking tot de Belgische situatie minder recent zijn dan die voor Vlaanderen. Om die reden wordt slechts af en toe verwezen naar de Belgische situatie.

Vanwege de vergelijkbaarheid, worden de bronnen en de analysetechnieken die gebruikt werden door Moens et al. grotendeels hernomen (4). De absolute aantallen zelfmoordcijfers zijn steeds herleid naar aantal zelfmoorden per 100000 inwoners en - waar vermeld - gecorrigeerd voor leeftijd aan de hand van directe standaardisatie. In de methode van directe standaardisatie gaat men uit van de leeftijdsspecifieke sterftecijfers van een onderzoekspopulatie en past deze toe op een standaardpopulatie. Op deze manier kan men het te verwachten aantal overlijdens in de standaardpopulatie berekenen in elke leeftijdsgroep. Opgeteld levert dit een totaal aantal te verwachten overlijdens op, gestandaardiseerd naar leeftijd. Zo zijn de cijfers in figuur 1 (zie resultatensectie) leeftijdsgestandaardiseerd op basis van de Belgische populatie anno 2001 als standaardpopulatie; alle zelfmoordcijfers in tabel 1 (zie resultatensectie) zijn leeftijdsgestandaardiseerd aan de hand van de Europese standaardpopulatie, zoals vermeld in de "European health for all database” $(7,8)$.

Mogelijke evoluties in zelfmoordaantallen zijn getoetst aan de hand van een lineaire regressie (fig. 1-3 in resultatensectie), waarbij een normale verdeling werd verondersteld en een $1^{\text {ste }}$-orde-autocorrelatie. Een analyse met een hogere-orde-autocorrelatie en hogere-orde-polynomen was niet mogelijk wegens het beperkte aantal tijdspunten.

In figuur 4 (zie resultatensectie) wordt het aantal verloren potentiële levensjaren (VPL) weergegeven voor enkele belangrijke doodsoorzaken. De berekening van het VPL-cijfer gebeurt als volgt: wanneer een overlijden gebeurt op leeftijd X, worden de verloren jaren tussen 1 en 64 jaar berekend met de formule '65-X'. Het totale aantal VPL voor een specifieke doodsoorzaak wordt vervolgens gedeeld door het aantal blootgestelde levensjaren (9). 


\section{Resultaten}

Zoals reeds bleek uit de studie van Moens et al. namen Vlaanderen en België in de voorbije decennia een weinig benijdenswaardige plaats in op het gebied van zelfmoordproblematiek (4). In de door deze auteurs bestudeerde periode - 1970-1995 - is de zelfmoordproblematiek in België en in Vlaanderen, ook in vergelijking met de meeste buurlanden, erg belangrijk en leidt, bijvoorbeeld, tot het tweede grootste verlies van potentiële levensjaren, zowel bij de mannen als bij de vrouwen.

\section{Evolutie van het aantal zelfmoorden in Vlaanderen 1990 - 2001}

In figuur 1 wordt de evolutie van de leeftijdsgestandaardiseerde zelfmoordcijfers in Vlaanderen weergegeven (5). De tijdreeks begint in 1990 en loopt tot en met 2001. Het aantal zelfmoorden per 100000 inwoners wordt weergegeven in totaal, maar ook apart voor mannen en vrouwen.

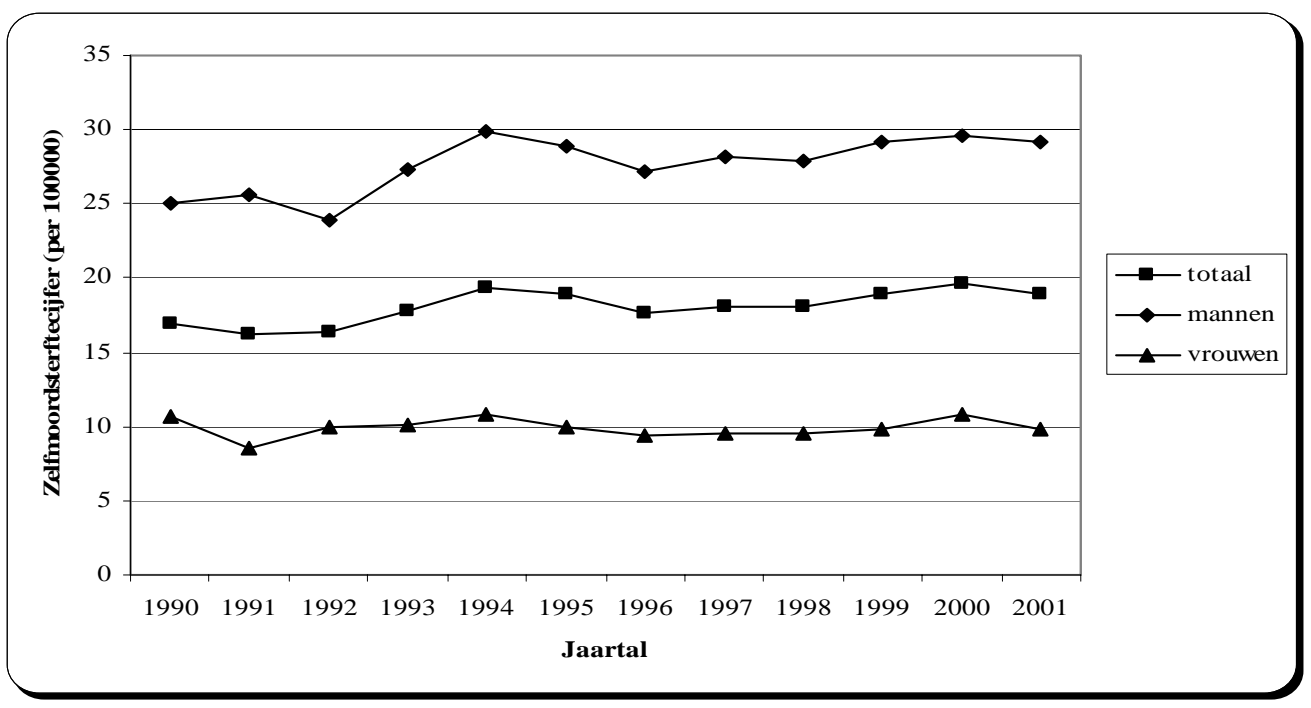

FIG. 1: EVOLUTIE VAN ZELFMOORDSTERFTE (PER 100 000 INWONERS) IN VLAANDEREN NAAR GESLACHT, 1990-2001 (5) (DIRECT GESTANDAARDISEERD VOOR LEEFTIJD MET BELGISCHE STANDAARDPOPULATIE 2001 (7)).

Vanaf 1992 was er een geleidelijke maar significante stijging van het totale aantal zelfmoorden per 100000 inwoners ( $p=0,0223 ; 0,22 / j a a r)$. Deze stijging werd veroorzaakt door het verloop van de zelfmoordsterfte bij de mannelijke populatie: vanaf 1992 werd bij mannen een toename zichtbaar in het aantal zelfmoorden per 100000. Tussen 1994 en 1996 daalde bij mannen het aantal zelfmoorden om daarna opnieuw toe te nemen. Dit verloop was ook terug te vinden bij de vrouwelijke populatie, zij het minder uitgesproken.

De zelfmoordcijfers bij mannen lagen consistent hoger dan deze bij vrouwen en vertoonden tussen 1990 en 2001 een significant stijgende trend ( $\mathrm{p}=$ 0,0118; 0,39/jaar). Bij de vrouwelijke populatie bleven de zelfmoordaantallen nagenoeg gelijk (geen significante toename). 
De recente evolutie naar leeftijd

In figuur 2 en 3 wordt het verloop van de sterfte door zelfmoord per leeftijdscategorie en per geslacht weergegeven.

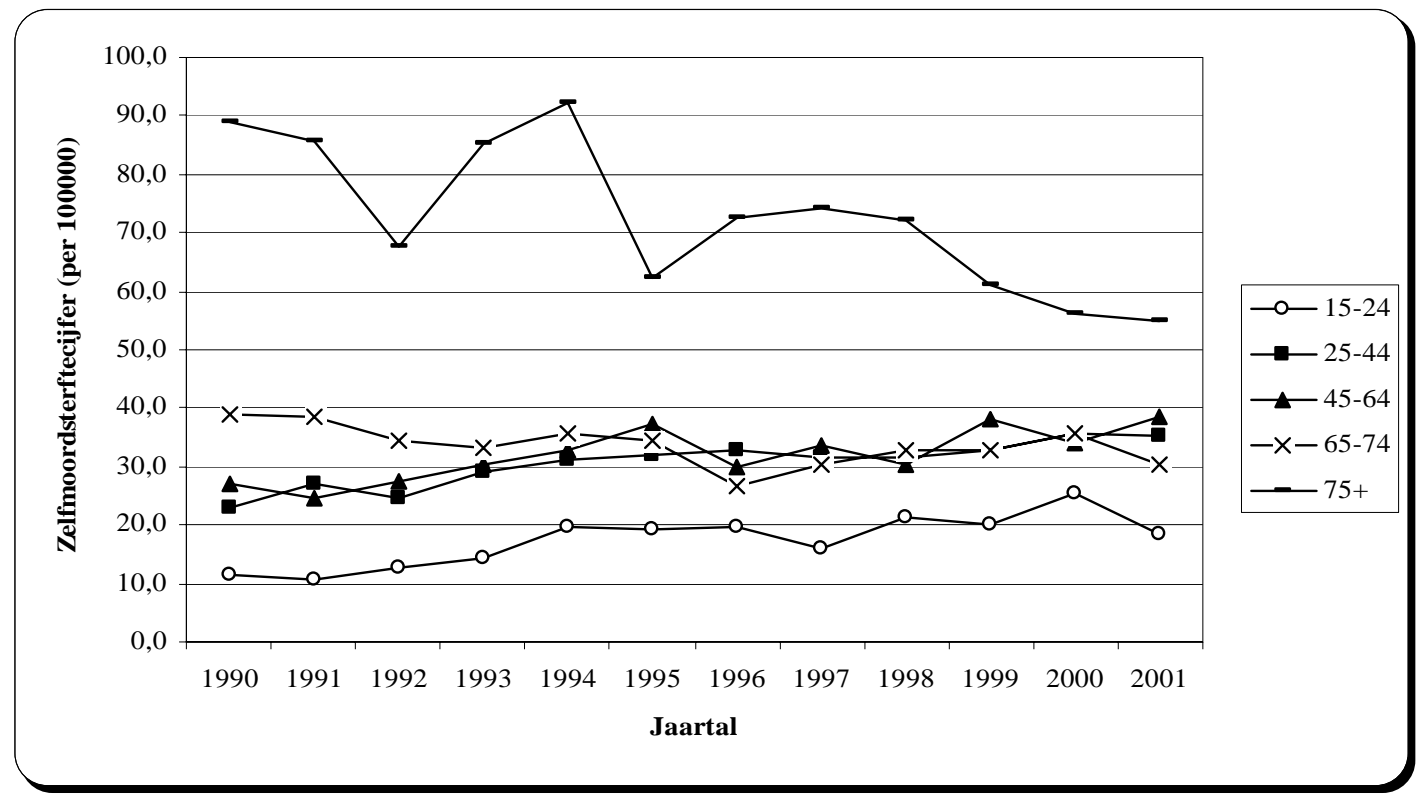

FIG. 2: ZELFMOORDSTERFTE PER 100000 MANNEN, NAAR LEEFTIJD, TUSSEN 1990 EN 2001 (5).

In 1990 stierven 89 mannelijke 75-plussers per 100000 inwoners ten gevolge van zelfmoord. In de groep 65- tot 74-jarigen waren er dat 39, onder de 45- tot 64-jarigen 27, onder de 25- tot 44-jarigen 23 en 12 bij de jongeren. In 2001 tekende men het hoogste sterftecijfer ten gevolge van zelfmoord op in de oudste leeftijdscategorie. Het tweede grootste sterftecijfer was dat van de 45- tot 64-jarigen en het derde dat van de 25- tot 44-jarigen.

De vierde plaats werd ingenomen door de tweede oudste leeftijdscategorie, de 65- tot 74-jarigen. In vergelijking met de andere leeftijdscategorieën was het sterftecijfer bij de 15- tot 24-jarigen zowel in 1990 als in 2001 het laagst.

In de oudste leeftijdscategorie is er tussen 1990 en 2001 een sterke afname van de sterfte door zelfmoord $(\mathrm{p}=$ 0,00; -2,75/jaar). In 1990 werden er 89 zelfmoorden per 100000 75-plussers geregistreerd, in 2001 nog 55. De zelfmoordsterfte in de leeftijdscategorie van de 65- tot 74-jarigen nam af vanaf 1990 en was het laagst in 1996: 27 zelfmoorden per 100000 inwoners in 1996 tegenover 39 per 100000 inwoners in 1990. Na 1990 nam het aantal zelfmoorden terug toe tot 36 per 100000 in 2000, om daarna opnieuw te dalen. Globaal genomen is het aantal zelfmoorden voor deze leeftijdscategorie licht gedaald tussen 1990 en 2001 ( $p=0,07 ;-0,57 / j a a r)$. De leeftijdscategorie van de 45- tot 64-jarigen vertoont een grillig, maar significant stijgend verloop, met uitschieters in 1995, 1999 en 2001 ( $p=$ 0,00; 0,99/jaar). In deze jaren steeg het sterftecijfer boven de 35 zelfmoorden per 100000 inwoners. Ook de 25- tot 44-jarigen vertonen een significant stijgende lijn (p = 0,00; 0,99/jaar). In 1990 telde men 23 sterfgevallen, 33 in 1996 en 35 in 2001. Bij de jongste leeftijdscategorie is er eveneens een geleidelijke maar significant stijgende trend ( $p=0,00 ; 1,03 / j a a r)$. 
Het topjaar was 2000 met 26 sterfgevallen per 100000 inwoners. Anno 2001 bedroeg het sterftecijfer bij de mannelijke jongeren nog 18 per 100000 inwoners.

Er is dus een lichte stijging merkbaar bij alle leeftijdscategorieën, behalve bij de twee oudste groepen.

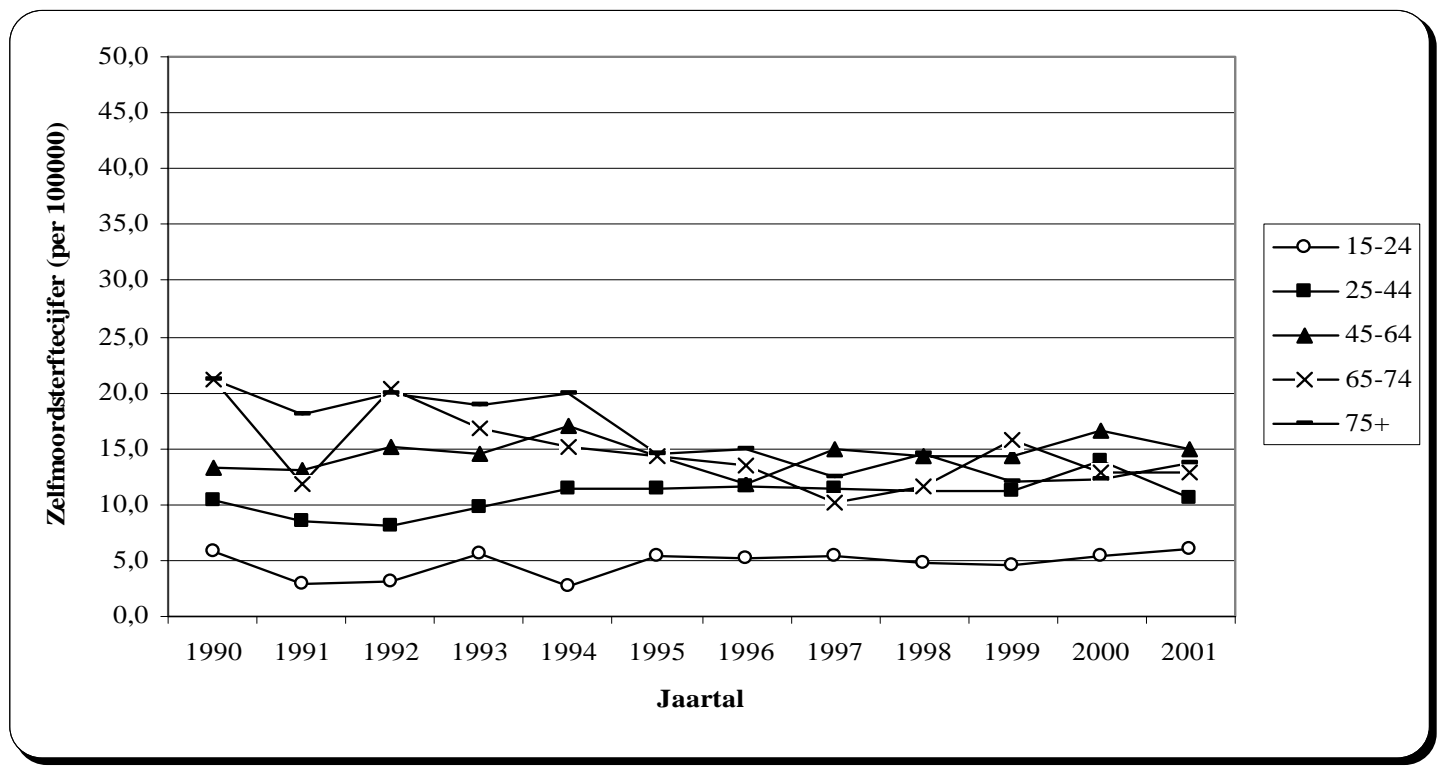

FIG. 3: ZELFMOORDSTERFTE PER 100000 VROUWEN, NAAR LEEFTIJD, TUSSEN 1990 EN 2001 (5).

De sterfte door zelfmoord per 100000 vrouwen ligt voor alle leeftijdscategorieën lager dan bij mannen. In het begin van vorig decennium was de zelfmoordsterfte het hoogst bij de oudere vrouwen. Naarmate de leeftijd afneemt, nam op dat moment ook het aantal sterfgevallen ten gevolge van zelfmoord af, zoals bij de mannen. In 1990 stierven in zowel de leeftijdscategorie van de 75-plussers als in de leeftijdscategorie van de 65- tot 74jarigen 21 vrouwen per 100000 inwoners door zelfmoord. In de groep 45- tot 64-jarigen waren er dat 13, onder de 25- tot 44-jarigen 10 en 6 bij de jongeren. In 2001 zien we een ander beeld. De groep van 45- tot 64-jarige vrouwen telde het hoogste sterftecijfer, op de voet gevolgd door de twee oudste leeftijdscategorieën. Voor de jongere leeftijdscategorieën veranderde er weinig.

Analoog aan de situatie in de mannelijke populatie, is er ook bij de vrouwen tussen 1990 en 2001 een significante afname van het aantal zelfmoorden bij de 65- tot 74-jarigen ( $p=0,01$; -0,51/jaar) en bij de 75plussers ( $\mathrm{p}=0,00 ;-0,83 /$ jaar). De zelfmoordsterfte lag voor beide leeftijdscategorieën relatief laag in 1991 en in 1997, om daarna opnieuw gering toe te nemen. De meest dramatische jaren waren 1990 en 1992, met respectievelijk 21 en 20 sterfgevallen per 100000 in beide categorieën. De zelfmoordsterfte bij de 45- tot 64jarige vrouwen nam het afgelopen decennium lichtjes toe van 13 sterfgevallen in 1990 tot 15 in 2001 (niet significant). In 1994 werden er in deze categorie 17 sterfgevallen per 100000 inwoners opgetekend. In de leeftijdscategorie van 25- tot 44-jarigen is het aantal zelfmoorden significant toegenomen ( $\mathrm{p}=0,01 ; 0,30 /$ jaar) . Topjaar was 2000 met bijna 14 zelfmoorden per 100000 inwoners. Ook bij de jongste leeftijdscategorie is er een geringe maar significante toename van het aantal zelfmoorden ( $\mathrm{p}=0,02 ; 0,16 / \mathrm{jaar}$ ). Het hoogste zelfmoordcijfer werd geregistreerd in 2001: namelijk 6 zelfmoorden per 100000 15- tot 24-jarigen. 
Waar dus een globale toename van het aantal zelfmoorden wordt opgetekend, blijkt dat dit niet het geval is voor de oudste leeftijdscategorieën: zowel bij vrouwen als bij mannen wordt hier eerder een lichte daling teruggevonden.

\section{De Vlaamse zelfmoordsterfte in internationale context}

In navolging van Moens et al. worden de zelfmoordsterftecijfers van 1992 en 2001 in Vlaanderen vergeleken met die van onze buurlanden (4). Op deze manier kan het fenomeen van zelfmoord in een internationale context geplaatst worden en kan men een idee krijgen van de relatieve ernst van het probleem in Vlaanderen.

TABEL 1: ZELFMOORDSTERFTECIJFERS IN VLAANDEREN EN IN EEN AANTAL BUURLANDEN IN 1992 EN $2001(5,6)$ (CIJFERS PER 100000 INWONERS, LEEFTIJDSGESTANDAARDISEERD MET DIRECTE METHODE EN EUROPESE STANDAARDPOPULATIE (8)).

\begin{tabular}{lcc|cc}
\hline Land & \multicolumn{2}{c|}{ Mannen } & \multicolumn{2}{c}{ Vrouwen } \\
& 1992 & 2001 & 1992 & $\mathbf{9 , 1}$ \\
\hline Vlaanderen & $\mathbf{2 0 , 8}$ & $\mathbf{2 6 , 6}$ & $\mathbf{8 , 8}$ & 5,6 \\
Duitsland & 22,6 & 18,6 & 8,0 & 8,2 \\
Frankrijk & 29,4 & 25,1 & 10,0 & 2,8 \\
Groot-Brittannië & 12,4 & 10,4 & 3,3 & 5,3 \\
Nederland & 13,5 & 12,1 & 6,7 & $10,7(\mathrm{a})$ \\
België & 25,5 & $29,6(\mathrm{a})$ & 9,9 & \\
\hline
\end{tabular}

(a) cijfer voor 1997

Uit tabel 1 blijkt dat in Vlaanderen in 2001 het zelfmoordsterftecijfer per 100000 inwoners bij zowel mannen als vrouwen hoger ligt dan dat in de buurlanden. Frankrijk staat wat betreft sterfte door zelfmoord op de tweede plaats. Erg opvallend is dat in alle buurlanden het sterftecijfer door zelfmoord tussen 1992 en 2001 daalde, zowel bij de mannen als bij de vrouwen. In Vlaanderen daarentegen nam het zelfmoordsterftecijfer voor de mannen toe, zoals reeds eerder aangehaald. Bij de vrouwen was de stijging miniem; dit staat echter in contrast met de daling in de andere landen.

De meest recente gegevens over België dateren van 1997. Toegepast op de Europese standaardpopulatie werden er toen 26,9 zelfmoorden per 100000 Belgische mannen en 10,7 per 100000 Belgische vrouwen geteld. Ook hier wordt zowel bij mannen als bij vrouwen een toename ten opzichte van 1992 aangetroffen.

\section{Sterfte door zelfmoord in vergelijking met andere belangrijke doodsoorzaken}

Zoals Moens et al. deden voor 1995, wordt in tabel 2 het absolute en het relatieve aantal overlijdens per geslacht en per leeftijdscategorie weergegeven voor enkele belangrijke doodsoorzaken in 2001. De doodsoorzaken die worden opgenomen, zijn: zelfmoord, verkeersongevallen, hart- en vaatziekten en kanker. Er wordt hierbij gekozen voor de twee belangrijkste doodsoorzaken bij volwassenen (hart- en vaatziekten en kanker) en de belangrijkste doodsoorzaak bij jongeren (verkeersongevallen). 
TABEL 2: ABSOLUUT EN RELATIEF AANTAL OVERLIJDENS DOOR ZELFMOORD EN ANDERE BELANGRIJKE DOODSOORZAKEN IN VLAANDEREN 2001 (5).

\begin{tabular}{|c|c|c|c|c|c|c|}
\hline \multirow[b]{2}{*}{ Leeftijdsklasse/Doodsoorzaak } & \multicolumn{2}{|c|}{ Mannen } & \multicolumn{2}{|c|}{ Vrouwen } & \multicolumn{2}{|c|}{ Totaal } \\
\hline & $\mathrm{N}$ & $\%$ & $\mathrm{~N}$ & $\%$ & $\mathrm{~N}$ & $\overline{\%}$ \\
\hline \multicolumn{7}{|l|}{ 15-24 jaar } \\
\hline - Zelfmoord & 67 & 20 & 22 & 18 & 89 & 19 \\
\hline - Verkeersongevallen & 174 & 52 & 52 & 43 & 226 & 50 \\
\hline - Hart- en vaatziekten & 11 & 3 & 6 & 5 & 17 & 4 \\
\hline - Kanker & 26 & 8 & 12 & 10 & 38 & 8 \\
\hline - Andere & 57 & 17 & 29 & 24 & 86 & 19 \\
\hline \multicolumn{7}{|l|}{ 25-44 jaar } \\
\hline - Zelfmoord & 315 & 27 & 89 & 15 & 404 & 23 \\
\hline - Verkeersongevallen & 233 & 20 & 66 & 11 & 299 & 17 \\
\hline - Hart- en vaatziekten & 163 & 14 & 77 & 13 & 241 & 14 \\
\hline - Kanker & 152 & 13 & 203 & 34 & 354 & 20 \\
\hline - Andere & 303 & 26 & 161 & 27 & 464 & 26 \\
\hline \multicolumn{7}{|l|}{ 45-64 jaar } \\
\hline - Zelfmoord & 291 & 6 & 104 & 4 & 395 & 5 \\
\hline - Verkeersongevallen & 97 & 2 & 26 & 1 & 123 & 2 \\
\hline - Hart- en vaatziekten & 1260 & 26 & 470 & 18 & 1730 & 23 \\
\hline - Kanker & 2084 & 43 & 1436 & 55 & 3519 & 47 \\
\hline - Andere & 1115 & 23 & 574 & 22 & 1689 & 23 \\
\hline \multicolumn{7}{|l|}{65 jaar en ouder } \\
\hline - Zelfmoord & 218 & 1 & 76 & 0 & 294 & 1 \\
\hline - Verkeersongevallen & 218 & 1 & 59 & 0 & 277 & 1 \\
\hline - Hart- en vaatziekten & 8072 & 37 & 10746 & 47 & 18818 & 40 \\
\hline - Kanker & 6545 & 30 & 4770 & 16 & 11315 & 24 \\
\hline - Andere & 6763 & 31 & 9192 & 37 & 15955 & 34 \\
\hline \multicolumn{7}{|l|}{ Alle leeftijden } \\
\hline - Zelfmoord & 838 & 3 & 301 & 0 & 1139 & 2 \\
\hline - Verkeersongevallen & 655 & 2 & 236 & 0 & 891 & 1 \\
\hline - Hart- en vaatziekten & 9567 & 34 & 11297 & 41 & 20864 & 37 \\
\hline - Kanker & 8949 & 32 & 6436 & 23 & 15385 & 28 \\
\hline - Andere & 8246 & 29 & 9247 & 36 & 17493 & 32 \\
\hline - Alle oorzaken & 28255 & 100 & 27517 & 100 & 55772 & 100 \\
\hline
\end{tabular}

In 2001 waren in totaal 1139 sterfgevallen het gevolg van zelfmoord. Dit zijn er 248 meer dan het aantal sterfgevallen ten gevolge van verkeersongevallen. 
Het aantal sterfgevallen ten gevolge van zelfmoord nam $2 \%$ in van het totale aantal sterfgevallen, $37 \%$ van de sterfgevallen was het gevolg van hart- en vaatziekten, 28\% van de sterfgevallen gebeurde ten gevolge van kanker. Het aantal overlijdens ten gevolge van zelfmoord ligt, tenzij bij de jongste groep, beduidend hoger dan dat ten gevolge van verkeersongevallen.

Het belang van zelfmoord als doodsoorzaak verschilt naargelang geslacht en leeftijdscategorie. Bij de jongeren (15- tot 24-jarigen) is zelfmoord verantwoordelijk voor ongeveer een vijfde van de sterfgevallen.

Verkeersongevallen zijn de voornaamste doodsoorzaak in deze leeftijdscategorie. Bij de 25- tot 44-jarigen is zelfmoord de belangrijkste doodsoorzaak bij mannen: 27\% van de sterfgevallen bij mannen is te wijten aan zelfmoord, 20\% aan verkeersongevallen.

Ook bij vrouwen is zelfmoord een voorname doodsoorzaak in deze leeftijdscategorie: 15\% tegenover (op de eerste plaats) 34\% aan kanker. In de oudere leeftijdscategorieën neemt het relatieve aantal overlijdens door zelfmoord bij beide geslachten af.

Terecht geven Moens et al. aan dat de berekening van het aantal “verloren potentiële levensjaren” (VPL's) in de productieve leeftijdsspanne van 15 tot 64 jaar een geschikte methode is om de economische impact van zelfmoord op de maatschappij weer te geven (4). Het VPL-cijfer geeft aan hoeveel levensjaren er voor die leeftijdsgroep verloren gaan per 1000 persoonsjaren. Hiermee geeft men het belang aan van doodsoorzaken die een voortijdig overlijden tot gevolg hebben. In figuur 4 wordt dit VPL-cijfer apart voor mannen en vrouwen weergegeven.

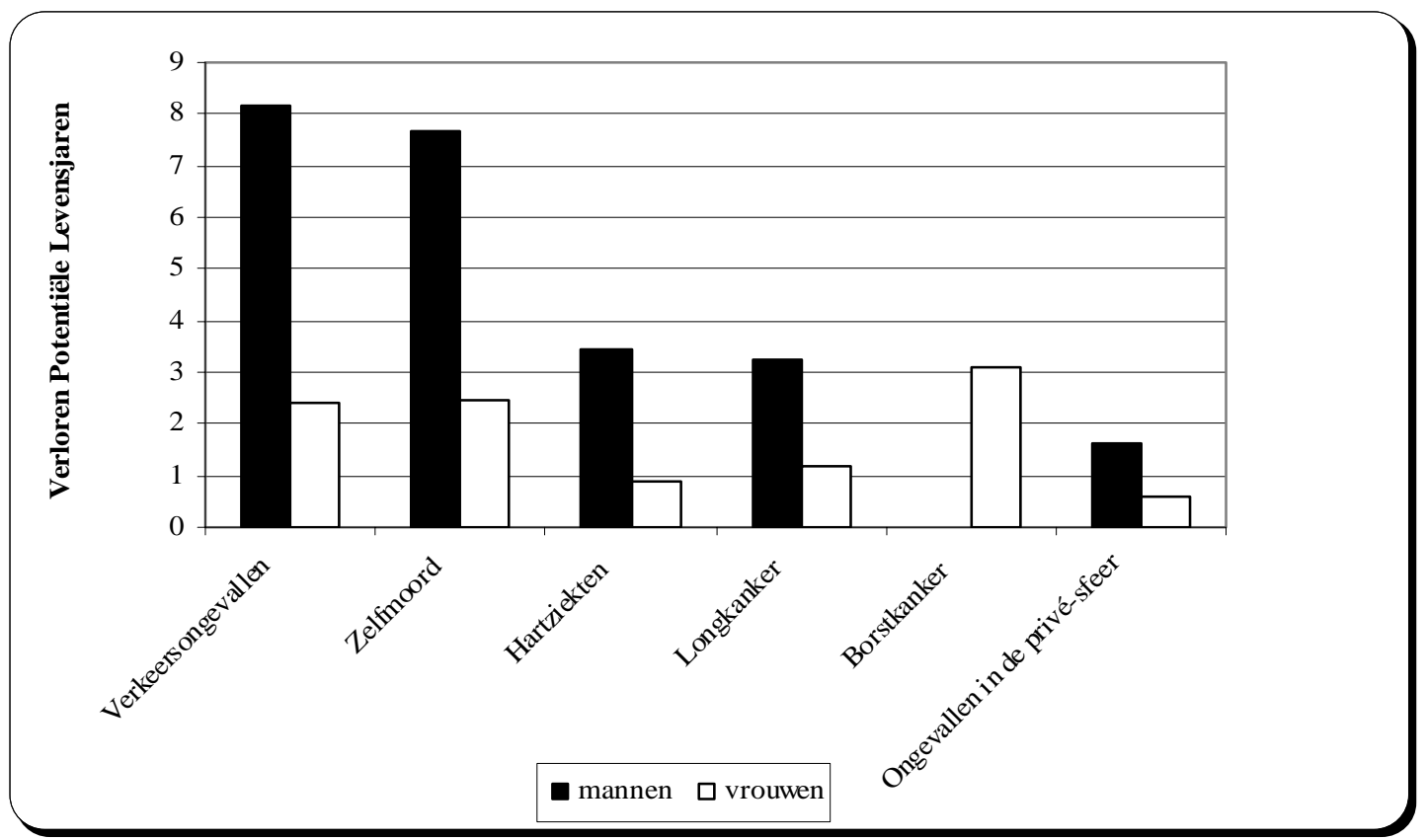

FIG. 4: AANTAL VERLOREN POTENTIËLE LEVENSJAREN IN DE LEEFTIJDSSPANNE VAN 16-64 JAAR, VLAANDEREN, 2001 (5).

Bij mannen waren de verkeersongevallen de belangrijkste oorzaak van vroegtijdig overlijden (acht VPL's per 1000 personenjaren), op de voet gevolgd door zelfmoord (7,5 VPL’s per 1000 personenjaren).

Bij vrouwen was borstkanker de belangrijkste oorzaak van vroegtijdig overlijden met 3 VPL's. Zelfmoord en verkeersongevallen veroorzaakten bij vrouwen elk ongeveer 2,5 VPL’s. 


\section{Evolutie van het gebruikte middel tot zelfmoord}

In figuur 5 en 6 wordt weergegeven welke middelen worden gebruikt om zelfmoord te plegen. Dit wordt apart voor mannen en vrouwen gedaan.

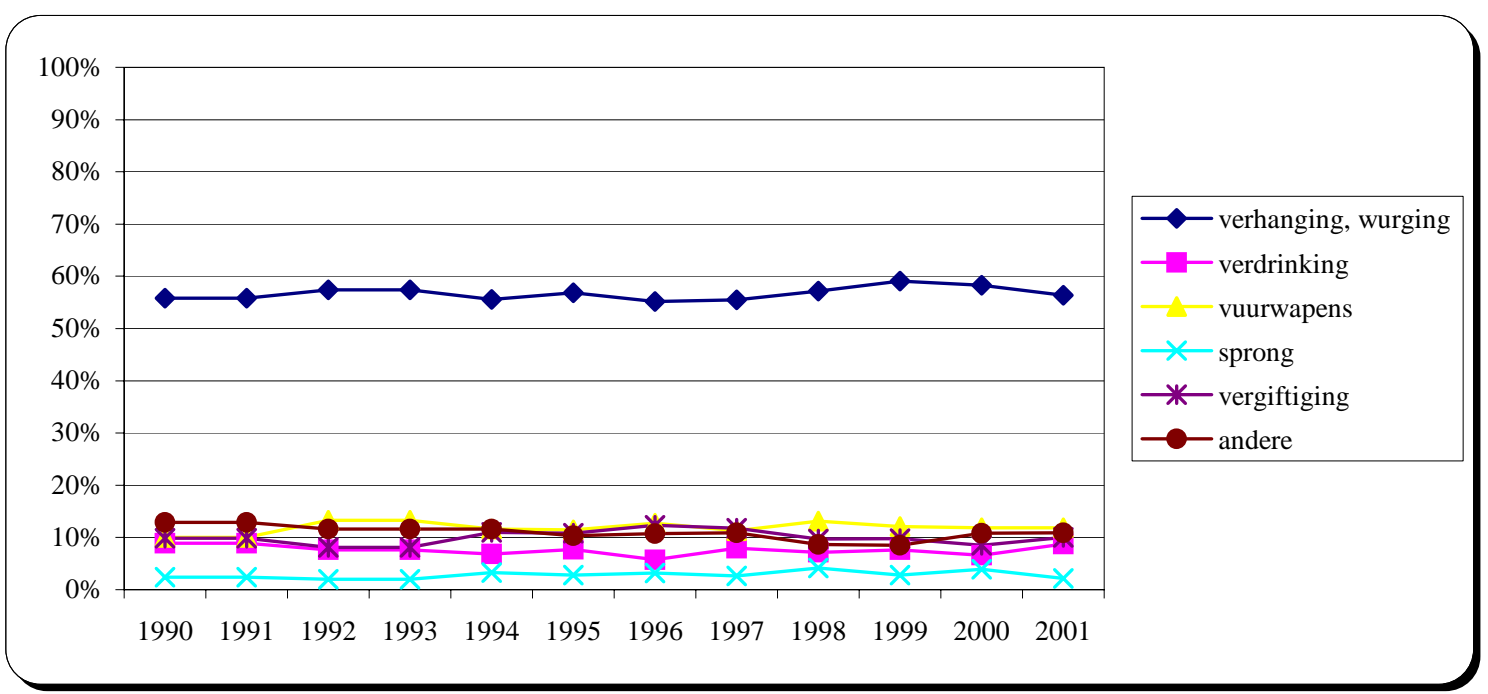

Fig. 5: PROCENTUELE WEERgaVE VAN RELATIEVE VERDELING VAN ZELFMOORDMIDDELEN BIJ MANNEN (1990-2001) (5).

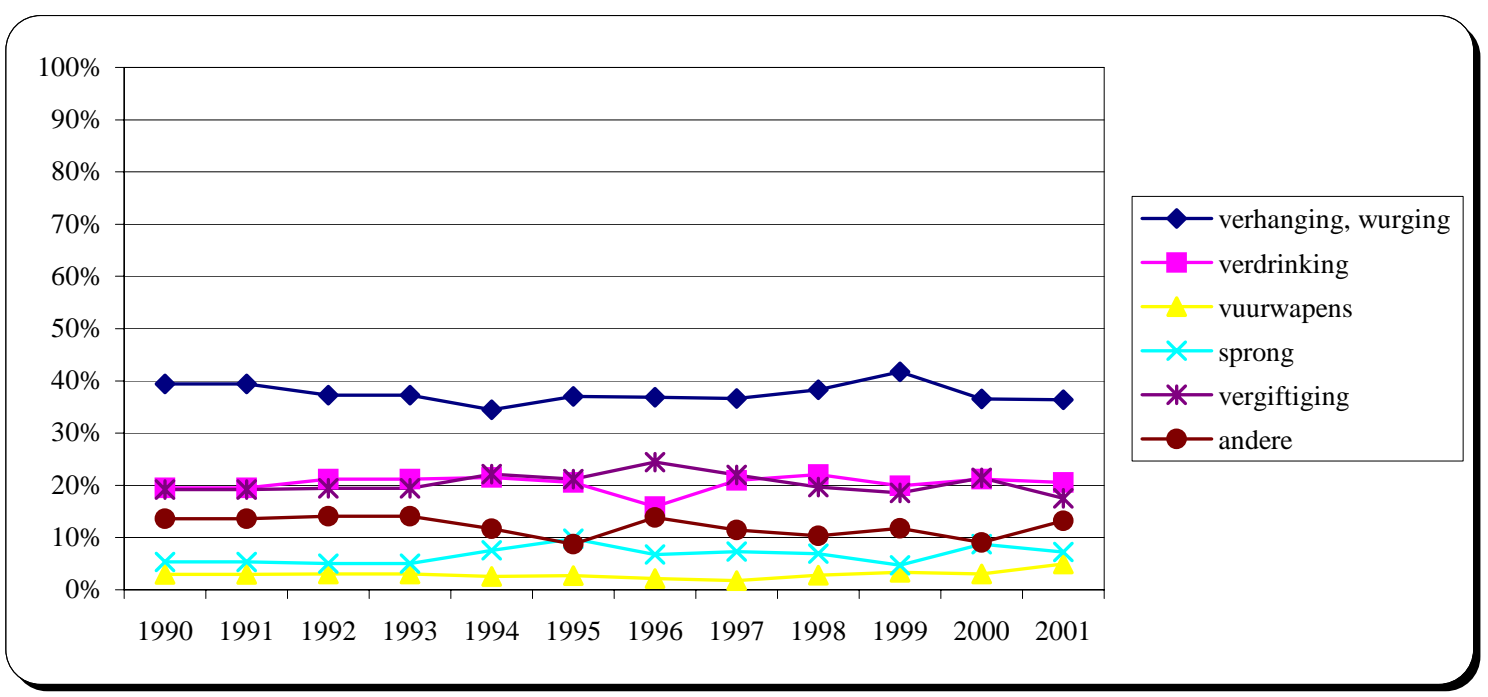

Fig. 6: Procentuele WEergaVe VAN RELATIEVE VERDELING VAN ZELFMOORDMIDDELEN BIJ VROUWEN(1990-2001) (5).

Uit figuur 5 blijkt dat er weinig verschuivingen optraden in gebruikte middelen door mannen om zelfmoord te plegen. Meer dan de helft van de zelfmoorden bij mannen gebeurde door verhanging, ongeveer $10 \%$ door verdrinking, vuurwapens of vergiftiging. Springen van een hoogte werd het minst gebruikt door mannen. Het aandeel van de verschillende zelfmoordmiddelen bij mannen bleef het afgelopen decennium nagenoeg gelijk. Ook bij vrouwen was verhanging het meest gebruikte middel (zie figuur 6). Vrouwen maakten echter, in vergelijking met mannen, relatief minder gebruik van verhanging en vuurwapens om zichzelf het leven te ontnemen en relatief meer van verdrinking, springen van een hoogte en vergiftiging.

Bij de vrouwen is de variatie in de tijd eveneens zeer beperkt. In 2001 was 36\% van de zelfmoorden bij vrouwen het gevolg van verhanging, 21\% gebeurde door verdrinking, 18\% door vergiftiging. 


\section{Schatting van de incidentie van zelfmoordpogingen}

Overlijdens ten gevolge van zelfmoord worden systematisch opgetekend, zelfmoordpogingen niet. Er ontbreken exacte gegevens over het totale aantal zelfmoordpogingen in Vlaanderen. Er moet beroep gedaan worden op schattingen op basis van de registraties van de huisartsenpeilpraktijken (Wetenschappelijk Instituut Volksgezondheid, Peilpraktijken 2001) en van de Eenheid voor Zelfmoordonderzoek van de Universiteit Gent (Eenheid voor Zelfmoordonderzoek, UGent, onder subsidie van het ministerie van de Vlaamse Gemeenschap). De methoden die bij deze verschillende bronnen gebruikt worden zijn, zoals uit de uiteenzetting zal blijken, erg uiteenlopend, zodat de schattingen die op basis van deze gegevens kunnen gemaakt worden soms erg verschillen en dus met voorzichtigheid moeten worden behandeld.

De huisartsenpeilpraktijken geven een indicatie van het belang van een aantal gezondheidsproblemen in de algemene populatie en bestuderen er de belangrijkste epidemiologische kenmerken van. Sinds de start van de huisartsenpeilpraktijken werden zelfmoord en zelfmoordpogingen driemaal opgenomen: in de periodes 19821983, 1993-1995 en 2000-2001. Het netwerk van huisartsenpeilpraktijken (150-tal huisartsenpraktijken) vertegenwoordigde in de laatste twee registratiejaren $1,5 \%$ van de Vlaamse en 1,6\% van de Waalse huisartsen en bereikte $1,5 \%$ van de bevolking. De peilpopulatie wordt geschat op basis van de vergelijking van het totale aantal contacten van de peilartsen met het totaal aan contacten van alle huisartsen op het niveau van het arrondissement.

De registratie van de huisartsenpeilpraktijken omvat alle gevallen van zelfmoord of poging daartoe die vastgesteld worden door een peil-/huisarts, een collega-huisarts tijdens wachtdienst, op een ambulante psychiatrische dienst of rechtstreekse opname in het ziekenhuis voor zover de peilarts hierover achteraf bericht kreeg. De registratie levert dus incidentiecijfers op.

De Eenheid voor Zelfmoordonderzoek van de UGent registreert zelfmoordpogingen in twee studies, de WHO/EURO Multicentre Study on Parasuicide en de Monitoring Studie Zelfmoordpogingen Vlaanderen. De WHO/EURO Multicentre Study on Parasuicide staat onder toezicht van de Wereldgezondheidsorganisatie en de commissie van de EU.

Deze studie loopt in 16 Europese landen en onderzoekt de epidemiologie van zelfmoordpogingen aan de hand van de registratie van karakteristieken van zelfmoordpogers in een geografisch goed afgebakend gebied (regio Groot Gent). Er gebeurt een registratie van gegevens van alle zelfmoordpogers die in aanraking komen met gezondheidsinstellingen in de regio Gent, waaronder algemene en psychiatrische ziekenhuizen, huisartsen, crisisinterventiecentra, gevangenis, enz. In de Monitoring Studie Zelfmoordpogingen Vlaanderen, opgestart door de Werkgroep Suïcide Onderzoek Vlaanderen (Wesov), worden het aantal zelfmoordpogingen en de kenmerken van zelfmoordpogers (+15 jaar), die in Vlaanderen onder de medische aandacht komen, geregistreerd.

Deze registratie gebeurt aan de hand van een uniform formulier en wordt uitgevoerd in de spoedopnamediensten van vier Vlaamse ziekenhuizen (U.Z. te Gent, A.Z. Sint-Jan te Brugge, Virga Jesse te Hasselt en A.Z. OostLimburg te Genk). Deze registratie wordt achteraf onderworpen aan een kwaliteitscontrole waarbij het onderzoeksteam de spoeddiensten bezoekt om de opnameregisters te vergelijken met het aantal geregistreerde zelfmoordpogingen. 
Op basis van de registratiegegevens uit zowel de Monitoring Studie Zelfmoordpogingen Vlaanderen als uit de WHO/EURO Study on Parasuicide is door de Eenheid voor Zelfmoordonderzoek van de UGent een schatting gemaakt van het aantal zelfmoordpogers in Vlaanderen per 100000 inwoners. Ook op basis van de registratiegegevens verzameld door de huisartsenpeilpraktijken in de periode 2000-2001 is een extrapolatie gebeurd naar zelfmoordpogingen per 100000 Vlamingen. Deze gegevens worden voorgesteld in tabel 3.

TABEL 3: SCHATTING VAN HET AANTAL ZELFMOORDPOGINGEN IN VLAANDEREN $2001(5,11,12)$.

Aantal zelfmoordpogingen per 100000 inwoners in Vlaanderen in 2001

\begin{tabular}{l|c|c|c}
\hline & $\begin{array}{c}\text { Monitoring Studie zelfmoord- } \\
\text { pogingen Vlaanderen }^{(11)}\end{array}$ & $\begin{array}{c}\text { WHO/EURO Multicentre } \\
\text { ("person-based”) }\end{array}$ & $\begin{array}{c}\underline{\text { Study }}^{(12)} \\
\text { ("person-based”) }\end{array}$ \\
Mannen & 109 & 136 & 55 \\
Vrouwen & 185 & 244 & 102 \\
Totaal & 146 & 192 & 79 \\
\hline
\end{tabular}

Op basis van de registratiegegevens van de vier spoedgevallendiensten (Monitoring Studie Zelfmoordpogingen Vlaanderen) wordt het aantal pogingen (“person-based”) voor Vlaanderen in 2001 geraamd op 146 per 100000 inwoners (10). Voor ditzelfde jaar bedragen de ramingen op basis van de registratiegegevens in de regio Groot Gent (WHO/EURO Multicentre Study on Parasuicide) 192 pogingen (“person-based”) per 100000 inwoners (11). Beide schattingen liggen ruim hoger dan het geschatte aantal pogingen berekend op basis van de gegevens van de huisartsenpeilpraktijken: 146 tot 192 zelfmoordpogingen per 100000 versus 79 per 100000 . Hierbij moet worden opgemerkt dat de verschillende registratiesystemen niet zonder meer met elkaar kunnen vergeleken worden, zoals reeds eerder aangehaald. Elk registratiesysteem heeft zijn specifieke beperkingen. Dit maakt dat elke omrekening naar absolute aantallen zelfmoordpogingen in Vlaanderen een verkeerd beeld van de werkelijke situatie zou opleveren.

Enkele mogelijke verklaringen voor de gevonden verschillen worden hierna genoemd.

In de Monitoring Studie Zelfmoordpogingen Vlaanderen registreren de spoedgevallendiensten van vier algemene ziekenhuizen het aantal zelfmoordpogingen. Men kan echter vermoeden dat een niet te onderschatten aantal zelfmoordpogers enkel door de huisarts wordt behandeld en opgevolgd, of via de huisarts rechtstreeks verwezen wordt naar ambulante hulpverlening, en met andere woorden ontsnapt aan het zicht van de spoedgevallendiensten. In de WHO/EURO Study on Parasuicide worden gegevens verzameld in Gent en 14 randgemeenten. Het betreft hier dus voornamelijk een stedelijke populatie, waarbij men zich kan afvragen in hoeverre deze een representatieve steekproef vormt van de Vlaamse bevolking. Voor de registratie van de huisartsenpeilpraktijken heeft men wel enig idee van de (geografische) representativiteit, aangezien vrijwel elk arrondissement vertegenwoordigd is. Echter, de betreffende incidentiecijfers zijn wellicht onderschattingen van de ware incidentie, aangezien personen zonder vaste huisarts niet zijn opgenomen in de registratie. Bovendien wordt de huisarts niet altijd op de hoogte gebracht van een zelfmoordpoging van één van zijn patiënten wanneer deze rechtstreeks in een ziekenhuis wordt opgenomen (zie tabel 4).

Zowel in de registratie van de huisartsenpeilpraktijken als de registratie in de Monitoring Studie Zelfmoordpogingen Vlaanderen, wordt een onderscheid gemaakt naar eerste hulpverlener, dit is de hulpverlener waar de patiënt eerst terechtkomt. 
TABEL 4: AANTAL ZELFMOORDPOGINGEN IN VLAANDEREN 2001, NAAR EERSTE HULPVERLENER (10, 13).

Percentage pogingen per hulpverleningsinstantie

\begin{tabular}{|c|c|c|}
\hline$\underline{\text { Registrerende partij }}$ & $\begin{array}{c}\underline{\text { Huisarts }} \\
\left.\text { (peilpraktijken }^{(10)}\right)\end{array}$ & $\begin{array}{c}\text { Spoedopnamediensten } \\
\text { (Monitoring Studie Zelf- } \\
\text { moordpogingen Vlaanderen }{ }^{(13)} \text { ) }\end{array}$ \\
\hline Ziekenhuis & $38,9 \%(28)$ & $41,3 \%(237)$ \\
\hline Huisarts & $52,8 \%(38)$ & 29,3\% (168) \\
\hline Andere & $8,3 \%(6)$ & \\
\hline Gemiste & & 29,4\% (169) \\
\hline
\end{tabular}

Bij de registraties van de huisartsenpeilpraktijken komt het merendeel $(52,8 \%)$ van de pogingen eerst onder de aandacht van de huisarts, alvorens te worden doorverwezen naar een ziekenhuis.

Uit de registratiegegevens van de Monitoring Studie Zelfmoordpogingen Vlaanderen (Eenheid voor Zelfmoordonderzoek) blijkt dat meer dan 40\% van de pogingen eerst onder de aandacht komt van het ziekenhuis, alvorens andere hulpverleners hierbij betrokken worden. Wie de voornaamste eerste hulpverlener is, verschilt dus naargelang wie registreert: de huisarts of de spoedgevallendienst. Volgens de registratie op de spoedgevallendiensten (Monitoring Studie Zelfmoordpogingen Vlaanderen) is de huisarts slechts in 29,3\% van de gevallen de eerste hulpverlener. Dit kan er op wijzen dat een belangrijk deel van de pogingen niet gekend wordt door de huisarts. Merk op dat het aandeel 'gemiste' vrij hoog ligt voor de Monitoring Studie Zelfmoordpogingen Vlaanderen. Op 169 registratieformulieren werd niet aangeduid wie de eerste hulpverlener was geweest bij de geregistreerde poging.

In de Monitoring Studie Zelfmoordpogingen Vlaanderen gebeurt ook een registratie van de verdere hulpverlening nadat de poger zich aanmeldde op de spoedgevallendienst. Dit is de instantie waar de poger terechtkomt na de eerste hulpverlening (cf. tabel 5).

TABEL 5: VERWIJSKANALEN ZELFMOORDPOGINGEN IN VLAANDEREN 2001 (13). Percentage pogingen per verwijsmodaliteit

\begin{tabular}{l|c}
\hline Hospitalisatie & $66,6(382)$ \\
Ambulante hulpverlening & $16,7(96)$ \\
Geen doorverwijzing & $6,3(36)$ \\
Andere/Gemiste & $10,5(60)$ \\
\hline
\end{tabular}

Twee derde van de pogers werd gehospitaliseerd. Een zesde werd doorverwezen naar ambulante hulpverlening en $6,3 \%$ werd niet doorverwezen. Ook hier overstijgt het aandeel onbekenden $10 \%$, te wijten aan de onvolledige invulling van de registratieformulieren voor het betreffende onderdeel.

Voor de zelfmoordpogingen stelt zich vervolgens de vraag naar de evolutie van dit probleem in de onderzochte periode. De gegevens uit de WHO/EURO Multicentre Study on Parasuicide tonen aan dat het totale aantal pogingen tussen 1987 en 1995 schommelde tussen ongeveer 320 en 420; vanaf 1996 is er een opmerkelijke daling tot ongeveer 200 à 250 pogingen per jaar per 100000 inwoners (8). 
Het lijkt er dus op dat er hier sprake is van een dalende trend. Opmerkelijk is dan wel dat het aantal zelfmoorden nog blijft toenemen tot 2001, terwijl intussen het aantal pogingen daalt.

Tenslotte moet opgemerkt worden dat het aantal pogingen bij vrouwen duidelijk hoger ligt dan bij mannen, terwijl dit voor zelfmoorden de omgekeerde verhouding is. 


\section{Besluit}

Vermits er tijd nodig is voor de registratie en verwerking van relevante gegevens, is het vrijwel onvermijdelijk dat epidemiologische gegevens met enige vertraging gepubliceerd worden. Dit geldt ook voor de hier besproken gegevens over zelfmoord in Vlaanderen, die slaan op de periode 1990-2001. Men moet er dus rekening mee houden dat de actuele situatie (anno 2006) mogelijk veranderd is in vergelijking met 2001. Met deze beperking in het achterhoofd kan echter niet anders dan vastgesteld worden dat in de periode 1990-2001 het aantal zelfmoorden in Vlaanderen is toegenomen.

Zelfmoord was in Vlaanderen één van de belangrijkste oorzaken van verloren potentiële levensjaren. Dit is uiteraard een zorgwekkende vaststelling. Het feit dat deze toename van zelfmoorden zich niet voordoet in de oudere leeftijdscategorieën maakt duidelijk dat het niet de zogenaamde vergrijzing van de bevolking is die deze stijging veroorzaakt.

Bovendien wordt duidelijk dat in de buurlanden in dezelfde periode het aantal zelfmoorden is afgenomen, terwijl het in Vlaanderen en België stijgt. Dit is wellicht de meest verontrustende vraag die door deze gegevens wordt opgeroepen: "hoe is te verklaren dat in Vlaanderen (België) de sterfte door zelfmoord in de beschouwde periode toenam, terwijl het probleem in de ons omringende landen afnam?” De beoordeling van de algemene tevredenheid van de bevolking over hun leven-in-het-algemeen, zoals gemeten in het kader van de Eurobarometer, biedt geen verklaring: de evolutie van de tevredenheid van de Belgen is op dit punt niet duidelijk verschillend van die van de landen waar het probleem van zelfmoord afneemt (14). Het is algemeen geweten dat het probleem van depressiviteit belangrijk is, en wellicht toeneemt, en dat zelfmoord één van de risico's is bij depressie. Ons zijn echter geen gegevens bekend die erop zouden wijzen dat het probleem van depressiviteit minder ernstig zou zijn in de buurlanden waar het aantal zelfmoorden in de beschouwde periode daalde. We worden hier dus geconfronteerd met een aantal vragen die voor de volksgezondheid van groot belang zijn en die dringend verder onderzoek vergen.

De door de Huisartsenpeilpraktijken gemaakte schattingen van het aantal zelfmoordpogers per 100000 inwoners in Vlaanderen (periode 2000-2001) werden vergeleken met de schattingen die door de Eenheid voor Zelfmoordonderzoek van de UGent zijn berekend op basis van registratiegegevens uit Monitoring Studie Zelfmoordpogingen Vlaanderen en WHO/EURO Study on Parasuicide. In 2001 zouden er op basis van registratiegegevens van de huisartsenpeilpraktijken 79 zelfmoordpogingen per 100000 Vlamingen zijn geweest. De ramingen berekend aan de hand van registratiegegevens van de WHO/EURO Multicentre Study on Parasuicide en de Monitoring Studie Zelfmoordpogingen Vlaanderen bedragen respectievelijk 146 en 192 zelfmoordpogingen per 100 000. Afhankelijk van het feit of de registratie gebeurde door de huisarts (huisartsenpeilpraktijken) of op de spoedgevallendienst (Monitoring Studie Zelfmoordpogingen Vlaanderen) kwam 51,8 of 29,3\% van de pogingen eerst onder de aandacht van de huisarts. Het merendeel van de pogingen werd gevolgd door een hospitalisatie. Hoewel er sinds 1996 een daling van het aantal zelfmoordpogingen geregistreerd wordt, wordt deze zelfde trend niet teruggevonden bij het aantal zelfmoorden. 
Op basis van voorgaande gegevens mag er geen twijfel over bestaan dat de zelfmoordproblematiek meer aandacht verdient dan ze in het verleden heeft gekregen. Volgens de Wereldgezondheidsorganisatie (WHO) is zelfmoord een aanzienlijk maar grotendeels te voorkomen publiek gezondheidsprobleem (15). De WHO heeft aldus van de vermindering van het aantal zelfmoorden een prioriteit voor het gezondheidsbeleid gemaakt. Ook in Vlaanderen is het probleem van zelfmoord uitgebreid besproken op de Gezondheidsconferentie "Preventie van depressie en zelfmoord” in 2002 (16). De uit deze conferentie voortgekomen gezondheidsdoelstelling stelt dat het aantal sterfgevallen door zelfmoord tegen 2010 met 8\% moet verminderd zijn ten opzichte van 2000 (16). De voorstellen om deze doelstelling te bereiken zijn talrijk en kaderen in een multidisciplinaire benadering van de zelfmoordproblematiek. De voorgestelde preventiestrategieën omvatten onder andere het ontwikkelen van richtlijnen voor de media met betrekking tot de verslaggeving over zelfmoord, het verschaffen van publieksinformatie/educatie over geestelijke gezondheid, het opzetten van een elektronische (zelfmoord)helplijn voor huisartsen, het screenen van zelfmoordpogers en het voorkomen van nieuwe zelfmoordpogingen door samenwerking met huisartsen (16). Een deel van de geplande acties zijn reeds in pilootvorm opgestart. Op basis van al deze voorstellen en in samenwerking met de sectoren die betrokken zullen zijn bij de implementatie ervan, is het de bedoeling om een meerjarenplan uit te tekenen.

De in dit artikel voorgestelde gegevens beschrijven de situatie tot 2001. Om een gefundeerde inschatting van de huidige omvang van de zelfmoordproblematiek (in 2006) te maken, is verder onderzoek aangewezen. Zoals gesteld, kan immers uit de hier besproken gegevens niet direct worden afgeleid dat de situatie in 2006 even ernstig is gebleven als in 2001. Verontrustend is wel dat de stijging tussen 1990 en 2001 vrijwel continu is, en dat de daling in het aantal pogingen niet teruggevonden wordt in het aantal zelfmoorden. Wanneer uit verder onderzoek zou blijken dat de stijgende trend in het aantal zelfmoorden zich ook na 2001 verder heeft doorgezet, moet men zich de vraag stellen of het realistisch is een daling van het aantal zelfmoorden als objectief te stellen. Wellicht is het op basis van deze bevinding realistischer om een stoppen van de stijgende tendens als doelstelling te formuleren. 


\section{Dankwoord}

We danken het Wetenschappelijk Instituut Volksgezondheid (Huisartsenpeilpraktijken), de Eenheid voor Zelfmoordonderzoek van de Universiteit Gent, en de Administratie Gezondheidszorg van het ministerie van de Vlaamse Gemeenschap voor het beschikbaar stellen van hun gegevens. 


\section{$\underline{\text { Literatuur }}$}

1. Bille-Brahe U. Sociology and suicidal behaviour. In: Hawton K, van Heeringen C, eds. The international handbook of suicide and attempted suicide. Chichester: John Wiley \& Sons, 2000: 193-207.

2. van Heeringen K, Kerkhof AJ. Behandelingsstrategieën bij suïcidaliteit. Houten: Bohn Stafleu van Loghum, 2000.

3. Hawton K, van Heeringen K, eds. The international handbook of suicide and attempted suicide. Chichester: John Wiley \& Sons, 2000.

4. Moens G, Capet F, Aelvoet W, Van Oyen H, Drieskens S, Van Casteren V. De recente evolutie van suïcidaal gedrag in Vlaanderen. Tijdschr Geneesk 1999; 55: 96-104.

5. Vlaamse overheid - Administratie Gezondheidszorg. Gezondheidsindicatoren; 2001.

URL: http://www.wvc.vlaanderen.be/gezondheidsindicatoren/

6. World Health Organization - Regional Office for Europe. European health for all database; 2001. URL: http://www.euro.who.int/hfadb

7. Federale overheidsdienst Economie, KMO, Middenstand en Energie. Ecodata: de bevolking in België per jaar, gemeente, nationaliteit, geslacht en leeftijdsklasse; 2001. URL:

http://ecodata.mineco.fgov.be/mdn/bevolking.jsp

8. World Health Organization - Regional Office for Europe. European health for all database; 2001. URL: http://data.euro.who.int/hfamdb/help/mTechnical.htm

9. Miermans PJ, Van Oyen H. Gezondheidsrapport: Een verkenning van de gezondheidssituatie in België aan de hand van sterftecijfers en gezondheidsverwachtingscijfers. Brussel: Wetenschappelijk Instituut Volksgezondheid - Afdeling Epidemiologie; 2002. Report No.: IPH/EPI Reports Nr. 2002 - 031.

10. Wetenschappelijk Instituut Volksgezondheid - Peilpraktijken. Percentage pogingen per hulpverleningsinstantie en verwijsmodaliteit; 2001. Unpublished.

11. Eenheid voor Zelfmoordonderzoek. Zelfmoordpogingen Vlaanderen; 2001. URL: http://allserv.ugent.be/ cvheerin/Zelfmoordpogingen\%20Vlaanderen.html

12. Eenheid voor Zelfmoordonderzoek. Zelfmoordpogingen Gent; 2001. URL: http://allserv.ugent.be/\%7Ecvheerin/Zelfmoordpogingen\%20Gent.html 13. Eenheid voor Zelfmoordonderzoek. Percentage pogingen per hulpverleningsinstantie en verwijsmodaliteit; 2001. Unpublished.

14. European Commission. Eurobarometer; 2001. URL:

http://www.europa.eu.int/comm/public_opinion/index_en.htm

15. World Health Organisation. Suicide huge but preventable public health problem, says WHO. Geneva, 2004. URL: http://www.who.int/mediacentre/news/releases/2004/pr61/en/

16. Van Hecke M, Dewolf D, Eggers K, eds. Verslagboek Gezondheidsconferentie: Preventie van depressie en zelfmoord. Brussel, 2002. 